\title{
The Local Context for Organizing in Nigeria
}

\author{
Temi O. Wright \\ Purdue University
}

Research in organizational identity has assumed a stable, democratic, political system in theorizing. Theories have also taken for granted an assumption of a stable economy and social environment of practice that make possible an effectual running of business. This, however, is not always the case. Practice outside the West find many of these theories faulty without local adaptations. This paper responds to the question of local adaptability by discussing environmental variables in Nigeria. To do this, I borrow from research in public relations which has provided environmental variables that practitioners must be aware of in order to localize research or practice in different environments. I discuss Nigeria's unstable political system, volatile economy and national culture which builds on research in cross-cultural studies. These serve on the one hand to demonstrate what organizational environments look like in Nigeria thereby showcasing deep-rooted values of organizational leaders and members. On the other hand, they also aid in the interpretation of organizational identity within organizations in Nigeria. An understanding of these variables will play a significant role in making sense of organizational identity and organizing in Nigeria. Findings are equally relevant to applied and engaged researchers and to practitioners in adjoining disciplines with interest in Nigeria.

\section{INTRODUCTION}

Until the 1970s, research (and practice) in organizational communication has been approached from a postpositive lens with little recourse to culture and the local context (Papa, Daniels \& Spiker, 2008; Redding \& Tompkins, 1988). Scholars from the interpretivist paradigm began to question the utility of research that did not pay attention to local culture and cross-cultural understandings (Geertz, 1973). Similarly, research in organizational identity has assumed a stable, democratic, political system (Gioia et al., 2013) in theorizing. Theories have also taken for granted an assumption of a stable economy and social environment of practice that make possible an effectual running of business. This can be seen in the conceptualization of organizations. This inadequacy in theories and recommendations for practice can be linked to the research on organizing being carried out primarily in similar environments with similar economies and political systems. Most of "what we know about organizational identity, including its dynamic aspects, is based on the study of organizations located within a single and uniform geographic market (U.S./European) and/or stable institutional environment (developed markets)" (Gioia et al., 2013, p. 180). Practice outside the West, however, finds many of these theories to be faulty without local adaptations. Pant and Ojha (2017) edited a special issue on organizational identity in the developing world. In this issue, researchers explored managerial values and organizational identity examining variables such as workplace spirituality, dual identity, corruption and Indian psychology in organizational 
identity for an understanding of the organizational self. Additionally, Glynn and Watkiss (2012) have examined societal culture, Jack and Lorbiecki (2007) reviewed the role of national identity, Kjærgaard, Morsing and Ravasi (2011) examined the influence of the media while Gioia at el. (2013), Hatch and Schultz (1997), and Hatch, Schultz and Skov (2015) iterated the importance of culture to organizational identity.

Incidentally, this argument is similar to critique of the excellence study in Public Relations which prior assumed and recommended a global theory of public relations developed from the study of over 300 organizations located in similar environments with little noteworthy cultural differences between practitioners and practice in the three nations studied (Grunig, Grunig, Verčič, 1998; White et al., 1982, 1987A, 1987B). This paper responds to the question of local adaptability by discussing environmental variables in Nigeria. To do this, I borrow from research in public relations (see Grunig, Grunig \& Verčič, 1998; Sriramesh \& Verčič, 2009), which has provided environmental variables that practitioners must be aware of in order to localize research or practice in different environments. I discuss Nigeria's unstable political system, volatile economy and national culture which builds on research in cross-cultural studies. These serve on the one hand to demonstrate what organizational environments look like in Nigeria thereby showcasing deep-rooted values of organizational leaders and members. On the other hand, they also aid in the interpretation of organizational identity within organizations in Nigeria. An understanding of these variables will play a significant role in making sense of organizational identity and organizing in Nigeria. Findings are equally relevant to applied communication and public relations scholars and practitioners with interest in Nigeria.

I begin this paper with a discussion of the political system. This is followed by a discussion of the level of economic development and the national culture in Nigeria.

\section{POLITICAL SYSTEM}

Nigeria is a non-Western, developing country with a population of 184 million people according to the Nigerian National Population Commission (www.population.gov.ng) with an average life expectancy of 54.5 years ("Countries: Nigeria," n.d.; "Nigeria: Life expectancy," n.d.). Nigeria is the most populous African nation and the nation with the highest number of black people in the world. It is commonly said that one in every five Africans you meet is a Nigerian. Nigeria is located in sub-Saharan West Africa, covering 356,669 sq. miles or 923,768 sq. km ("Nigeria country profile," 2017). Having gained independence from British colonial rule in 1960, the nation became a Federal republic in 1963 and joined the Commonwealth of Nations led by President Nnamdi Azikiwe and Prime Minister Tafawa Balewa. Nigeria is a leading member of the Economic Community of West Africa (ECOWAS) and also a member of other international organizations such as the United Nations, African Union, the World Trade Organization, among others.

English is Nigeria's official language and thus the language of education, commerce and government, though Lagos state in February 2018 adopted Yorùbá language as a requisite language as well ("LASG: Yoruba Now Mandatory," 2018). The 1999 Constitution of the Federal Republic of Nigeria is also written in English. Indigenous languages are also in full use in the different regions occupied by indigenous groups (Koper, Babaleye \& Jahansoozi, 2009, p. 312). It is a general rule of thumb, however, that although English is the official language and indigenous languages are very common, speaking Nigerian pidgin English, known locally as "broken English" or simply "pidgin," is more effective in getting around the country. It also serves as a way for in-group membership and language for socialization.

Nigeria is divided into six geo-political zones - North West, North East, Middle Belt, SouthWest, South East and the South South. Nigeria also has divisions among ethnic groups, with the major three being Yorùbá, Hausa and Igbo. The Yorùbá people occupy most of SouthWest Nigeria while the Hausa people occupy the North and the Igbo, the Eastern part of Nigeria. There are approximately "250 ethnic groups, with [the] three major tribes constituting over 40 percent of the population" (Koper, Babaleye, Jahansoozi, 2009, p. 312). Other than these three, major ethnic/linguistic groups include the Edo people, 
Ijaw, Efik, Fulani, Kanuri, Ibibio, Tiv, Nupe, Gwari, Igala, Jukun, Igbira, Idoma, Itsekiri, Urhobo and the Anang, with approximately 374 dialects (Koper, Babaleye, Jahansoozi, 2009, p. 312; Findlay, 2017).

Nigerians are very religious, with 91 percent reporting that they attend religious services (Prinz, 2012, p. 46), and the country boasts of "the largest Muslim population in sub-Saharan Africa" (Gov.uk., n.d. B) with Sharia law adopted by 12 states in Northern Nigeria (Freedom House, 2017). The major religions are Islam, Christianity and local indigenous faiths (Koper, Babaleye, \& Jahansoozi, 2009, p. 312). This is important. Khari and Sinha (2017) showed that workplace spirituality in developing countries can add value to organizational identity and knowledge sharing intention among organizational members.

Nigeria is a federal republic: a "democrac[y] wherein multiple parties and individuals compete in open elections to earn the right to rule for a predetermined period" (Sriramesh \& Verčič, 2009, p. 6). Elections are conducted every four years for the office of the president and other major offices of government. Because of ethnic dividing lines, however, Nigeria practices what is known as "federal character" (see http://www.federalcharacter.gov.ng). Essentially, this is an effort by the government to ensure representation of members of the different ethnic and cultural groups in government and civil service. Currently, the president is Mohammed Buhari, a Hausa man, while his vice president is Yemi Osinbanjo, a Yorùbá man.

Nigeria operates a multi-party-political system. Political parties, however, gather around the interest to take over political power rather than shared ideologies. As a result, cross carpeting is very common with little identification with party and ideology. It is common to find power-hungry politicians switch parties and suddenly support those they previously vehemently criticized. Often times, even those that were outspoken against government corruption are later indicted of being guilty of similar offenses. It is the norm for former leaders to be probed and tried on allegations of corruption. In 2016, the Buhari government arrested many top military and government officials on allegations of corruption. Between 2015 and mid 2017, the government had recovered US\$9 billion in stolen assets. (Freedom House, 2017, p. 10).

Transparency International ranks Nigeria as the 16th most corrupt nation in the world with a score of 27 where 0 is the height of corruption out of 100 (Transparency International, 2018). The corruption perception index also highlights the connection between corruption and inequality which is very pervasive in Nigeria (Transparency International, 2017). The key to keep in mind is how these affect the approach to business and may create a difference in the founder's vision of organizational identity and those of organizational members. Corruption has enjoyed social acceptance in Nigeria, thus there may be strategic frictions in their visions. Sahu (2017) contributed to this discourse a perception on corruption that shows that collectivism as a cultural factor may contribute to this where organizational members may not easily distinguish between what is collectively owned and what is corruption.

Although on paper, Nigeria operates a pluralistic democracy with the involvement of its citizens, it is widely believed that it is run as a country for the elite and privileged. Those with wealth or power continually oppress those without. Even government agencies set up to serve and protect Nigerian citizens use their positions to exploit the people. For example, the Nigerian National Petroleum Corporation (NNPC), rather than protect and regulate the nation's oil wealth so as to serve its citizens, has served as a channel for further looting the nation's oil wealth. The police randomly stop and search citizens hoping to obtain a bribe, and government agents often demand bribes as fees for them to do their jobs. This is common in almost every agency. Peter Enahoro, who wrote the humorous satire How to be a Nigerian, separates this abuse into two different levels. There is "dash" and there is "bribe." What government officials often take is regarded by them as dash--a fee or tip for appreciating them for doing their job. Only, this fee comes before the job; without it, your request will not get fulfilled (Enahoro, 1966, pp. 3537). The dash can be seen as a form of pay-to-play scheme (Shapiro, 2014). The courts aren't much better and ideals like justice or fighting for fair treatment through the court are myths to the ordinary Nigerian (Freedom House, 2017, para. 32).

Sadly, corruption in Nigeria neither starts nor ends with the government and its agents. It is very common to find counterfeit versions of anything. Copyright and intellectual property is not well respected and entertainment products are often dubbed and sold openly. Other forms of corruption rampant in 
Nigeria include advance-fee (419) fraud (Oriola, 2005; Smith, Holmes \& Kaufmann, 1999), widespread sexual harassment (Johnson, 2010; Ladebo, 2003) and discrimination against women (Freedom House, 2017, para 2).

Unfortunately, Nigeria's corruption also leads to the production and selling of counterfeit and substandard food and medications which kill in large numbers. When former head of the National Agency for Food and Drug Administration and Control (NAFDAC), Dr. Dora Nkem Akunyili, took office in 2001, one of her motivations in combating fake drugs was that she witnessed fellow citizens including her sister die because they fought "killer diseases like malaria and tuberculosis with little more than sugar syrup and chalk tablets, cynically packaged to look like the real thing" (Frenkiel, 2005, para. 4). Half of all drugs in circulation at the time were counterfeit or substandard - even in hospitals. Surgeons unknowingly administered fake adrenalin (which was just water), sub-strength muscle relaxant and other sub-par drugs in attempts to save lives. To Akunyili, this was "the highest form of terrorism against public health" (Frenkiel, 2005, para. 8). Corruption, however, fought back, NAFDAC offices were set ablaze and there was an assassination attempt on her life in 2003 (Johnson, n.d.). She survived and NAFDAC has been largely successful in clamping down on the sale and distribution of fake or substandard food and medication in Nigeria.

In the next section, I discuss the economy in Nigeria. This exists on the backdrop of the ongoing political sphere which certainly affects or impedes economic growth and organizational development. One obvious example of the interaction between the political and economic spheres is the billions of dollars purloined by former heads of State, for example, General Sani Abacha who Transparency International in 2004 ranked as the $4^{\text {th }}$-most corrupt leader in the world (Hodess, 2004, p. 13). Removing so much money from the system destabilizes the economy and weakens the market. It threatens organizations and frustrates the efforts of managers and practitioners. Corruption in leadership has thus plagued the economy and organizations for years. Between 2000 and 2011, more than 1,600 companies closed business in Nigeria owing to harsh operating environment (Premium Times, 2012; Alli, 2009). "Political and economic factors" were a major concern in the mix according to the president of the Nigerian Association of Chambers of Commerce, Industry, Mines and Agriculture (Premium Times, 2012, para. 4). Similarly, the 2016 federal budget was signed five months late in May because of bizarre political hindrances such as budget padding and the mystical disappearance of the budget (Aziken, 2016; Freedom House, 2017). These political mishaps continue to gravely perturb the economy, making it more and more difficult to operate a stable business within it. I turn now to an overview of the Nigerian economy.

\section{ECONOMY}

Nigeria's economy is considered a managed, emerging market economy or frontier market (Shapiro, 2014). "The essence of a market economy is to create opportunities, facilitate competition and guarantee consumers' choice" (Clement, 2017). Goldman Sachs' 2005 BRICS report of fast-growing economies predicted that Nigeria will be among the 20 largest economies by 2050 (O'Neill, Wilson, Purushothaman, and Stupnytska, 2005, p. 8; Sriramesh \& Verčič, 2009). At the time of the Goldman Sachs' report, Economic growth was 5.1\% but it has slowed since 2014 culminating in a 2016 recession.

Following a 2014 rebasing of the Nigerian economy to account for growing industries such as telecommunication, manufacturing, film and entertainment among other things, Nigeria became Africa's largest economy at US\$510 billion ("Nigeria's GDP: Step change," 2014). It also ranked $24^{\text {th }}$ largest in the world, ahead of Belgian and Taiwanese economies ("Nigeria's GDP: Step change," 2014). In 2006 under president Olusegun Obasanjo, Nigeria became the first African nation to pay off its debt to the Paris Club of lenders aided by high oil prices and a pardon of US\$18 billion (Koper et al., 2009) of the US\$30 billion the country was owing the club ("Five things you should know about Paris Club," 2017; "Nigeria profile - Timeline," 2017).

The local currency is the Naira (N) and is regulated by the Central Bank of Nigeria in Abuja and the Nigerian Stock Exchange in Lagos. The Central Bank of Nigeria values the naira at 305.96 to \$1 (USD) 
at the inter-bank rate and N360.47/US\$ at the "investor and exporter window" while the parallel market exchanges at $\$ 362 /$ US\$ ("Lagos parallel market rates," n.d.), although this fluctuates very frequently. The Central Bank of Nigeria puts inflation at 15.37 percent year-on-year ("Economic report fourth quarter 2017," n.d., pp. 2 \& 21).

"Nigeria is a dream market" for its demographics and consumption, - gigantic, exposed (Jadesimi, 2015, para. 3) and highly indulgent with almost half of its population urban and under 30 (Gov.UK., n.d.; "Nigeria's population now," 2017). It is a vibrant group of consumers full of potential and hungry for market consumption. However, poor economic management and high inequality in the distribution of wealth has led to high unemployment and low purchasing power. The 2016 per capita income was reportedly \$1,976 (USD) ("Nigeria economic outlook," 2018). In the third quarter of 2017, the Nigerian National Bureau of Statistics reported youth unemployment at $18.8 \%$ and underemployment at $21.2 \%$. Essentially, 52.65\% (or 10.96 million unemployed, 11.68 million underemployed) of this young vibrant group have either no work or work below their skills and credentials (National bureau of statistics, n.d.; National bureau of statistics, 2017, p. 2). This along with high power distance affects managers' view of their human resources as dispensable, as well as how stakeholders feel about their role and relationship to the organization and its identity.

With the discovery of oil in 1956, there was an abandoning of agriculture and the economy became oil-dependent. Nigeria shifted from being a major exporter of agricultural products to becoming an importer in just 50 years owing to oil dependence. Furthermore, oil mining and spills have also damaged the oil rich, riverine areas of the South South damaging farming in that region. The oil boom in the " $70 \mathrm{~s}$ owing to increase in oil prices meant that other means of gross domestic production were ignored to embrace the sudden windfall of oil wealth. This boom, however, had its consequences. Sriramesh and Verčič (2009) warned of this. The state must carefully direct economic and fiscal policies, and provide needed infrastructure to even out the effects of windfall wealth and neoliberal policies which, while great, can have negative effects if adopted too quickly or without careful and intentional management - as has been the case in Nigeria.

These outcomes have trickled down negative effect to the functioning of business as inflation, dependence on oil, economic volatility and lack of needed infrastructure have all contributed to challenges facing business firms in Nigeria. Thus, beyond competing for profit, businesses are often in a struggle against the economy to stay alive in business. As such, like Nigerians in the general society, organizations may tend to be aggressive in their outlook to business and competition. This may, however, hold the inadvertent effect of actually strengthening ties with organizational members. As Scott and Lane (2000) noted, "people's perceived overlap with an organization will enhance their self-esteem (i.e., the attractiveness of the overlap) ... to the extent that they view prototypical characteristics of the organization as consistent with the norms, values, and definitions of the embedding culture" (p. 49). Thus, an organization reflecting tendencies that are consistent with Nigeria-specific values and practices (in this case, in terms of daily competitiveness and the drive to survive) will foster a stronger sense of identity among organizational members.

In Africa, Nigeria is the largest producer of crude oil (Carpenter, 2015; Dibie, 2017), the 12th largest producer in the world at 1.87 million barrels of crude oil produced daily ("Country Comparison: Crude oil - production," n.d.) and the sixth largest exporter of crude oil in the world ("Country Comparison: Crude oil - exports," n.d.). Before the 2016 recession and vandalism of oil pipelines, Nigeria readily produced up to 2.6 million barrels per day (Carpenter, 2015). Petroleum reserves remain the 10th largest in the world ("Country Comparison: Crude oil - proved reserves," n.d., Koper et al., 2009. p. 321) with 37.06 billion barrels proved reserve as of January 2017 ("Field listing: Crude oil - proved reserves," n.d.).

The economy has experienced erratic growth and failures affected directly by "fluctuations of the global oil market" ("Nigeria economy," n.d., para. 2) prices and demand; and exacerbated by Nigeria's own internal problems. Over almost 60 years of independence, Nigerians have experienced increased population growth and continuous decline in standard of living ("Nigeria economy," n.d.). The bigger challenge has been the effect of macroeconomic management (or mismanagement) by the government, as Sriramesh and Verčič (2009) argued, and how these trickle down to affect organizations. Nigeria has not 
been successful in diversifying the economy although there have been efforts by successive governments with the Structural Adjustment Programme (Mbachu, 1991), the National Economic Empowerment and Development Strategy (NEEDS) (International Monetary Fund, 2005) and the Agricultural Transformation Agenda ("ATA-Nigeria," n.d.).

Nigeria suffers from a "resource curse" or the "Dutch disease" (Saibu \& Loto, 2017). Empirical studies (e.g., Ahmadov, 2012; Haouas \& Heshmati, 2014) have shown that oil production income often leaves "negative development impact and the drivers of economic growth ... are vulnerable to external shocks outside of its control" (Saibu \& Loto, 2017, p. 207). Nigeria is a classic case of this. Increases in global oil prices have not meant increased standard of living as Nigeria also lacks sufficient infrastructure to refine its own crude oil consumption. It imports refined oil, which increases cost of living as well as the cost of running a business. Oil has been a double-edged sword, central to Nigeria's economy at the macro and micro levels as Nigeria's oil reliance is not only for external revenue but also internal daily operations. Lacking electrical power infrastructure means there is ineffective electricity supply. Thus, for subsistence, citizens and businesses rely on power generators. "The manufacturing industry as a whole operates on more than 70 per cent of energy it generates" itself using refined petroleum (Premium Times, 2012, para. 6). Oil has also remained a key rallying point for political and economic tensions in the country including the 1967 civil war, nationwide strikes such as the one against the 2012 oil subsidy removal (Abutu, 2014; Igwebuike, Abioye, \& Chimuanya, 2016), and civil unrest such as militancy, oil pipeline vandalism and kidnappings in the Niger Delta region. All these continue to contribute to very high costs of running business and instability that culminated in the 2016 recession.

To escape recession, the government designed the Economic Recovery Growth Plan (2017-20) and the Seven Big Wins to reform the petroleum industry and sharply move the country off its dependence on oil. Efforts are to be driven by six identified key economic sectors: agriculture (cocoa, cassava, yams, cowpeas, beef, cashew, maize, palm oil, rice, groundnuts, plantain, ginger, cotton, horticulture); manufacturing; solid minerals (including iron, gold, and coal); services (including information and communication technology, financial services, tourism, and creative industries); real estate (and construction); and oil and gas ("African development bank," 2018). These efforts, an upturn in global oil prices and a deescalation of the Niger Delta pipeline vandalism crisis helped bring Nigeria out of recession by the second quarter of 2017 (National bureau of statistics, 2017). GDP growth in 2017 grew out of the recession in the negatives (-1.5\% in 2016) to $0.8 \%$. The African Development Bank predicts positive growth up to $2.1 \%$ in 2018 and $2.5 \%$ in 2019. ("African development bank," 2018).

All these help drive home the argument that environmental variables make a difference in how organizations function. On the one hand, "the dynamics between political and economic systems often determine a nation's stability and further economic development" (Sriramesh \& Verčič, 2009, p. 5). On the other hand, the absence of stability "directly affects variables such as poverty and illiteracy" (Sriramesh \& Verčič, 2009, p. 8) and organizations and organizational members' orientation to organizing. In the next section of this paper, I take a look at national culture and tease out culture as another environmental variable that affects organizational identity in Nigeria. Given the aforementioned political-economic setting, it may already be clear and indicative how Nigerians may be affected by the environment and the societal culture formed. Hofstede and other scholars provide the framework with which I discuss culture.

\section{CULTURE}

Culture "affects behaviour and interpretations of behaviour" (Spencer-Oatey, 2012, p. 4). It is the body of unquestioned assumptions which goes on to shape how and why organizational members behave and communicate the way they do (Lustig \& Koester, 2013). To be successful, scholar-practitioners with interest in Nigeria must reckon with the Nigerian culture and understand actions as cultural group members, "insiders", interpret them (Hofstede, 1991, p. 8).

The Nigerian culture is shaped by historical context, traditions of its many people(s) and current socio-political circumstances. Nigeria was not a single territory until 1914 after the amalgamation of the 
Northern and Southern protectorates under Lord Lugard ("Nigeria: past," n.d., para. 7) following the 1884-85 Berlin Conference to divide Africa among European superpowers (Wesseling, 1996). Before this unification, what is today Nigeria was just different territories with their own very distinct cultural groups and practices. Amalgamation, and later, independence, forced this distinct bodies of people to begin to see themselves as one and work together to build a nation that will serve their distinct identities and goals.

According to the Ethnologue on languages of the world (Nigeria, n.d.), there are 526 known living languages in Nigeria and seven extinct ones. There is also as many dialects and ethnic and sub-ethnic groups. For instance, while Yorùbá is a major Nigerian language, the Ijebu subethnic people of Southwestern Nigeria speak both the general Yorùbá but also have their own dialect called Ijebu, thus making a distinction in a subethnic sense. Probably owing to migrations and development, a good number of these languages are sadly "developing," "vigorous" "in trouble" or facing the threat of "dying" (Nigeria, n.d.).

Many Nigerians hold on tightly to their cultural origins. There is a lot of respect for their own traditions and cultural beliefs. As an example, Koper et al. (2009) provides that "election campaigning cannot succeed in local communities without the blessing of the traditional rulers and the cultural custodians" (p. 319). An easy example is the 2015 elections that saw the incumbent president, Dr Ebele Jonathan, paying homage and visits to the palaces of major traditional rulers to get their blessings, win their support and by extension, the support of those governed by them in the elections ("Channels Television," 2015; Daniel, 2014).

Although these rulers do not hold much political power under current democratic dispensation, their influence is far reaching since especially "rural population to a very large extent relies heavily on the opinion of the traditional rulers" (Koper et al., 2009, p. 319). This is owing to the strong sense of identification and beliefs Nigerians hold in regards their own cultural traditions, above loyalty to state or identity as Nigerians or any other.

Coleman (1958) referred to this idea as an omnibus concept (pp. 425-426). In his view, Nigerians display "five different sorts of nationalism at once - 'African,' 'Nigerian,' 'Regional,' 'Group,' and 'Cultural'" (Geertz, 1973, p. 257). Of all these, their strongest loyalty is often to the cultural nationalism or what Emerson refers to as "terminal community" which is that community that "when the chips are down, effectively commands men's loyalty, overriding the claims both of the lesser communities within it and those that cut across it or potentially enfold it within a still greater society" (Geertz, 1973, p. 257). This is most evidently demonstrated in the 1967 civil war which divided Nigeria across cultural or ethnic lines. Even when abroad, Nigerians form identification with their own ethnic group and may hold community meetings with them but are less interested in similar community meetings designed for all Nigerians.

As Jack and Lorbiecki (2007) found, "national identity can have a profound influence on organizational identity" just as societal culture affects and shapes organizational identity (Glynn \& Watkiss, 2012). Thus, "investing and operating a commercial business in the Federal Republic of Nigeria requires understanding the culture and predispositions of its residents" (Shapiro, 2014, p. 3). It is not for those unwilling to learn its history, political economy and conflicts.

Beyond the surface aspects of society, it is important to look into the deep structure of the community in order to get at an understanding of the culture. According to Hall and Hall's (1990) classification of cultures along communication and context, Nigeria is a high-context, polychronic society. There is an expectation of implied meaning by the physical environment or shared values and beliefs. "Most of the information is already in the person, while very little is in the coded, explicit, transmitted part of the message" (Hall \& Hall, 1990, p. 6). The Yorùbá people have a saying that one does not speak with the whole mouth. Similarly, we only say half of what we mean to the child born of great character. When it sinks in her/his mind, it will become whole. These essentially iterate the idea of the society as high context. Only a little needs to be explicitly said. A lot is left unsaid and little background information is provided in conversations. Communication is often indirect, time is more open and flexible, and the community favors relationships over everything else. 
As with high-context cultures, Nigerians have very large family networks. "Family" includes extended relatives who keep in touch very regularly. Nigerians keep "extensive information networks among family, friends, colleagues, and clients... who are in close personal relationships" (Hall \& Hall, 1990, p. 6). It is expected that you are aware of what is going on in the lives of anyone who occupies this close personal relationship status. It is actually taken as an offense when you do not make it your business to know what is going on in the life of a relative or a close acquaintance. Thus, relatives will ask deep questions which may otherwise be considered prying. To reject providing them with this information is to begin a quarrel. This information is also permissible to be shared among other close relatives. On the other hand too, as a member of that community, you cannot hear of another person's burden or challenges and not act on it. It is your duty as an in-group member to be concerned with their affairs and provide support when needed.

Similarly, businesses are run with this idea of shared information and knowledge. In low-context cultures, appointment is key and what enters the office (guests or information) is controlled (Hall \& Hall, 1990). Low-context cultures also emphasize olfactory and auditory filtering keeping noise, strong smells and interruptions away when set to work. In Nigeria, as with high-context cultures, this is less regulated. Nigerians "reject auditory screening and thrive on being open to interruptions and in tune with what goes on around them" (Hall \& Hall, 1990, p. 9). There is free movement of information and visitors in and out of a manager's office.

Appointments are rarely private and it is normal that a "meeting is interrupted by phone calls and/or visits from your client's friends and family" (Palk, 2010). It is also expected that organizational members are informed of what is happening across the organization and who has what information (Palk, 2010). It is almost like how the family network is supposed to be abreast of what is going on in everyone's life.

Furthermore, space and territoriality are less defined in Nigeria. Nigeria has a very large population but not the land mass to accommodate its size. Worse still is that industrialization and employment are concentrated in a few cities thus making the country densely populated in certain areas. Lagos is the most densely populated city in Africa with a population around 20 million people (Karuga, 2017; Sdunkwu, 2017). Housing is very costly in urban areas and since there is no strict regulation on the number of occupants per square foot of any residence, there tend to be lots of homes housing many more people than can conveniently fit (Mogo, 2016; Rosenthal, 2012). This is the same with office spaces, recreation spaces among other things that should otherwise provide quality of life. As a result, there is a reduced sense of personal space among Nigerians and the "invisible bubble" which Hall and Hall (1990) described is often penetrated even by strangers (InterNations, n.d.; Palk, 2010). Some Nigerians would also touch and poke very repeatedly during conversation showing the use of expressive haptics in conversation. Touching, cutting a person during conversation or being physically close show signs of interest and intimacy.

On the other end of this too is that idea that neighbors often tend to be very close in their relationship with one another. It is in a sense, everyone's responsibility to look out for the other. This extends to keeping an eye on your neighbors' children, reporting when you notice something out of place with the neighbor or their house or receiving the neighbors' mail, taking down a message for your neighbor or even entertaining their guests while they're away. Neighbors also borrow things very often from one another. Neighbors will also get involved in the errands, work, cooking and other plans or needs when you have a party or other engagement. Essentially, neighbors become an extended part of your family that lives next to you. The rule is that to be a good neighbor, you must be willing to share what you have and be involved in the lives of your neighbors. After all, Nigeria is a collectivist community ("Hofstede insights," n.d.).

Communities like Nigeria where there is little multisensory spatial screening and in which information and guest flow is not as regulated also tend to be polychronic in their orientation to time. "Polychronic time means being involved with many things at once" (Hall \& Hall, 1990, p. 13). This explains why private meetings are easily interrupted and time is very fluid. Schedules are not paramount; rather, relationships are paramount (InterNations, n.d.). "There is more emphasis on completing human 
transactions than on holding to schedules" (Hall \& Hall, 1990) and "personal relationships are often more important than regulations and laws" (Palk, 2010).

A Nigerian will not honor commitments but relationships when making a promise. Palk (2010) described the business culture as one in which "negotiations are fluid and what's agreed on Monday might not necessary mean the same thing on Tuesday" (Palk, 2010, para. 2) as polychronians "change plans often and easily" (Hall \& Hall, 1990, p. 15). Politicians and others with power will make promises, declare intentions to people and never fulfill them - they never planned to. People as a result are very suspicious of promises made by leaders and people in power.

Since time is so unbounded in Nigeria, it is okay to arrive a little tardy to a meeting or an appointment - although organizations work very hard to prevent this. Excuses are often made for arriving late such as "unusual" traffic in Lagos (InterNations, n.d.) - whereas it is a known fact that Lagos experiences extreme traffic conditions every day. Thus, rather than working to efficiently plan around time and social circumstances, it is generally accepted that time is beyond one's control and being late or going over time at a meeting may be inevitable.

Nigerians spend the earliest portion of a meeting waiting for others to join the meeting. This time is also used to make merry, greet one another, ask about work in other departments, ask after colleagues' relatives, make jokes and get comfortable with one another (InterNations, n.d.). Nigerians don't always get straight to the point and end up talking about things that may be irrelevant to the purpose of the gathering; but then, Nigerians are polychromic; relationship building matters and they prefer to spend some time getting comfortable around one another before discussing serious business. Hall and Hall (1990) described polychronic cultures as "considering time commitments an objective to be achieved, if possible" (p. 15).

While Edward T. Hall looked at culture as communication through context and orientation to time, Dutch social psychologist Geert Hofstede provides six dimensions of national culture which can also help in understanding the cultural environment in which organizations in Nigeria operate. These are the degree of power distance, individualism, time orientation, indulgence, uncertainty avoidance and masculinity (Hofstede, Hofstede \& Minkov, 2010). For Hofstede, these are programmed in the mind from a very young age and these determine how a society functions as well as what is the acceptable norm of behavior. These differences will likely affect the nature of organizational identity particularly as being coconstructed and negotiated by organizational members.

The first of Hofstede's cultural dimensions is power distance. This refers to how a society deals with inequality (Hofstede, 2011). It is "the extent to which the less powerful members of institutions and organizations within a country expect and accept that power is distributed unequally" ("Hofstede insights," n.d.). In Nigeria, power is distributed very unequally and both those in power and those subordinated feel this power distribution is sometimes an entitlement (as in traditional rulers) or the will of the almighty God(s) (as in spiritual leaders or those in higher hierarchical positions such as political or organizational leaders). Because God cannot be questioned, neither should the authority of those in power. Yorùbá kings are called kabiyesi meaning the unquestionable one. Spiritual leaders are believed to speak directly from the almighty God(s) and so they should also not be challenged. Nigeria's colonial past and ensuing military dictatorships where political and military power served to bully and subjugate the people have further reinforced this power distance. Osemeke and Osemeke's (2017) research on culture and organizational governance found this to be prevalent even in private industries.

In Nigeria, power distance is translated as "respect" (Palk, 2010). It is not so much about reverence but power and this power is achieved through age, position and money. People will defer the most amount of "respect" to those with the greatest amount of these. Osemeke and Osemeke (2017) described respect as a "way of life of the people" (p. 329) and is perhaps one of the few things all cultural groups in Nigeria agree on (Osemeke \& Osemeke, 2017; Wallace, 1992). As a result, the different ethnic groups in Nigeria strive to get an in-group member into positions of high authority and power at both organizational and political levels; "whether he/she does not know the job is irrelevant" (Osemeke \& Osemeke, 2017, p. 329). This leads to cronyism and impedes organizational and national development. 
Furthermore, in-group membership is very important in Nigeria as Nigerians are very collectivist. Collectivism, the next of Hofstede's cultural dimensions, is "related to the integration of individuals into primary groups" (Hofstede, 2011, p. 8). This is the cultural nationalism referred to earlier in this section of the paper. "People from birth onwards are integrated into strong, cohesive in-groups, often [of same ethnic origin,] extended families (with uncles, aunts and grandparents) that continue protecting them in exchange for unquestioning loyalty, and [will often] oppose other in- groups" (Hofstede, 2011, p. 11). This is the root of relationship being key for polychronic Nigerians. In-group networks are often very large but cohesive and maintained through the roles of elders who serve as moderators.

A Nigerian is considered a strong member of his or her in-group regardless of where in the world $\mathrm{s} / \mathrm{he}$ is. Being a high-context community, this member, though abroad, is still expected to be abreast of what is going on in the family and in-group network, contribute whenever needed and continue to fulfill traditional roles as expected. It is very common to find Nigerians travel back to Nigeria for their weddings, rites of passage and even funerals as maybe dictated by tradition. It is believed that no matter how long you spend traveling abroad, you will eventually return home. Thus, home is where your ingroup is rather than where you live.

Additionally, Hofstede presented cultures as having a time dimension: short versus long term orientation "related to the choice of focus for people's efforts: the future or the present and past." Hofstede (2011, p. 8). Nigeria is very short term oriented. This is perhaps responsible for the pronounced use of honorifics and titles; respect for elders and values for that which has passed, is ancient or of the ancestors. In Nigeria, age is everything and elders are seen as the "custodians of the tradition and culture" (Koper et al., 2009, p. 319). Age determines social roles and who must defer honor to whom. In a social gathering, the eldest person has roles s/he must fulfill. The younger person cannot sit while the elderly stands. The older ones should eat first and choose the best of all things. Younger people take what is left. The person who has spent the longest time around would be the wisest. This person is also usually the eldest in the room. It is often said that "no matter how many clothes a child has, s/he can never have as many rags [i.e., experiences] as the elderly".

Similarly, there is the tendency to maintain the norm as what is different is suspicious or bad. Nigerians often prefer to keep things the same even if those things are clearly not working. There is little tendency for adventure, being thrift or enduring for the future. There is always a lament or longing for the past as the "most important events in life occurred in the past" (Hofstede, 2011, p. 15).

Closely related to short term-orientation is the high indulgence orientation. Of all scores on Hofstede's cultural dimensions, this is the dimension in which Nigeria scores the highest. According to Hofstede (2011), countries high on indulgence often have a "higher percentage of people declaring themselves very happy" (p. 16). Nigeria is an optimal example of this. Despite economic and societal challenges, Nigerians are generally very happy people and indulge in a lot of merry making; and in 2003 and 2010 were ranked the happiest people in the world by a World Values Survey (Bond, 2003; "Nigeria tops happiness survey," 2003) and a Gallup global poll (Adegoke, 2017; Channels Television, 2012) respectively; and in 2011, ranked the most optimistic people in the world (Adewunmi, 2011; Channels Television, 2012).

"Indulgence versus Restraint [is] related to the gratification versus control of basic human desires related to enjoying life" (Hofstede, 2011, p. 8). Though the economy may recess, Nigerians' consumerism appetite remains unperturbed "as evidenced by it being ... one of the largest markets for Guinness in the world" (Jadesimi, 2015, para. 3). Every weekend in Lagos ushers in a stream of merriment from funerals on Fridays, weddings on Saturdays and birthday celebrations for elders on Thursdays and Sundays. Lagosians spent $\$ 1$ billion ( $\$ 6.2$ million USD) monthly on merriment according to the Lagos state government (Akoni \& Olowoopejo, 2013).

Furthermore, on Hofstede's cultural dimensions is uncertainty avoidance. It is not about avoiding risk but dealing with ambiguous or unknown situations. "It indicates to what extent a culture programs its members to feel either uncomfortable or comfortable in unstructured situations" (Hofstede, 2011, p. 10) such as when encountering that which is new or unusual. Nigeria has a mid-level uncertainty avoiding culture. There is some tolerance for ambiguity but not too much and there is the common belief that 
"'there can only be one Truth and we have it"' (Hofstede, 2011, p. 10). Thus, Nigerians often feel the need to "correct" anyone who deviates from dominant values.

Nigerians simultaneously accept unknown futures as these cannot be determined except by the higher power that controls the world. Nigerians enjoy the present, take each day as it comes and leave the future to take care of itself. There is little planning for ambiguous situations and people are often complacent even when it is clear that a little anxiety and planning would help achieve a more definite outcome. Sriramesh \& Verčič (2009) provided that this is related to being high-context as these cultures are "known to tolerate greater levels of ambiguity" (p. 12). At the same time however, Nigerians worry about what happens after death; and the different religions prescribe "the guidelines" for living in order to reach that preferred end. Nigerians thus, while relaxed, also get anxious about making it to paradise.

Nigerians are not very adventurous. They do not like to try new things and will not enter situations that are completely unfamiliar such as traveling to a new environment where there is no known in-group member; or leaving a job for an uncertain goal. Nigerians often build careers around jobs they do not even like - although this can be attributed to economic uncertainties. The common rhetoric is that it is better to stay on the job you are sure of and which provides a paycheck than veering off adventurously and then not finding work. The proverb for this is about a foolish person who, seeing lightning, throws out old water in buckets in the hope of fetching new rain water. What if it then doesn't rain? Only throw out the one you have when you see that certainly, new rain has come.

Last in this discussion is masculinity versus femininity. This is not so much about the individual but the community. What values are more upheld - feelings or work? "Admiration for the strong" or "sympathy for the weak"? (Hofstede, 2011, p. 12). How are values and roles split between the genders in the community? Is it important to be "very assertive and competitive and maximally different"? (Hofstede, 2011, p. 12).

Nigerian culture is very patriarchal. Girls have roles they are expected to fulfill and so do the boys who are not expected to show emotion. Children are raised following gender guidelines and gender is sufficient reason to be allowed or prevented from doing certain things. For example, because a child is male, from birth, he is raised to recognize that he must provide for his family financially, be concerned about stability of the future on behalf of others and would become responsible for his parents and younger relatives' livelihood (if need be) when he grows older. These roles are ascribed from birth (Parsons \& Shils, 1951). The girl child must also sit in a certain way which is more "girly," and she must be more conscientious and neat. She must recognize that her goals for life must be devised with caution as they must align with those of her husband. She is raised learning how to raise a family but not to be financially independent. The male should be strong, assertive, ambitious and always fight back. It is tabooed for the roles to be switched. Tradition and religious thoughts are used to justify many of these convictions.

Nigeria is a masculine-dominated culture "driven by competition, achievement and success" ("Hofstede insights," n.d.). Success in Nigeria is understood as working hard, but more importantly, being wealthy. Nigerians are competitive in and outside of work. Everything is seen as a competition - against neighbors, family friends, co-workers, random people and even where there is no actual competition. Competitiveness sometimes involves physical tactics like pushing and, in extreme cases, punching. The Nigerian senate and house of representatives have been sites for showing this part of the Nigerian society to the world. Deliberations have often led to fisticuffs (Jones, n.d.).

As seen from the discussion, culture is very important to organizing in Nigeria. The organization itself "is a social actor that reflects cultural themes and interprets cultural resources in the construction of "who we are' and "what we do" (Glynn \& Watkiss, 2012). As a result, cultural sentiments and beliefs play a significant role in organizational construction and operations. As with other environmental variables, recognizing the role of culture helps better understand and interpret organizational identity.

\section{CONCLUSION}

As can be seen in the above discussion of the environmental variables, "business in Nigeria is not for those unwilling to become informed about its history and current conflicts affecting its political economy" 
(Shapiro, 2014, p. 3). The Nigerian environment is significantly different from what is obtainable in many Western nations. As Kaplan and Manners (1972) argue, the social structure is one of the determinants of culture. (Other determinants include technoeconomics, ideology and personality.) Social structures including the political and economic state of societies will affect the way people behave as well as their deep-rooted values. They strongly affect how the culture of the social group is formed and how organizations are run in that social environment. Thus, in aligning "identity with prevalent cultural sentiments and through the use of cultural mechanisms, an organization [may] gain audience acceptance, thereby conferring legitimacy and value on the organization (Glynn \& Watkiss, 2012)" (Gioia et al., 2013, pp. 163-164).

For the sake of studying organizational identity, as the concept may be realized in Nigeria, it is important to recognize that "in Nigeria the way of life of the people is often used as a standard to determine how a company should be run" (Osemeke \& Osemeke, 2017, p. 329). It should thus be expected that even concepts of organizational identity such as the negotiation of identity through the interactions of organizational leaders and members may be challenged because of cultural values such as power distance. Similarly, economic and political concerns may also come in effect in both how organizational members see their organization as well as the extent to which identity plays a central role in the conduct of business. Thus, even the concept of endurance or continuity may be challenged in this environment and perhaps replaced with dynamic cultural framing in showing "cultural fit" with current environmental sentiments (Gioia et al., 2013, p. 163). It may be expected that in resilience to environmental factors, newer or other conceptions of organizational identity may be realized. These conceptions may then play the key role in successfully running an organization in Nigeria.

\section{ACKNOWLEDGEMENT}

I would like to acknowledge Dr. Josh Boyd at Purdue University and my thesis committee for their guidance and support in shaping my thesis work on which this paper was originally based.

\section{REFERENCES}

Abutu, O. P. (2014). Consequences of the January 2012 oil subsidy removal in Nigeria. Journal of Business and Retail Management Research, 8(2), 24-29. Retrieved from $\mathrm{http}: / /$ www.scopus.com/inward/record.url?eid=2-s2.0-84905993729\&partnerID=tZOtx3y1

Adegoke, Y. (2017). Nigerians are still happy, this is a problem. The Guardian. Retrieved from https:/guardian.ng/features/nigerians-are-still-happy-this-is-a-problem/

Adewunmi, B. (2011). Nigeria: The happiest place on earth. The Guardian. Retrieved from https://www.theguardian.com/global/2011/jan/04/nigerians-top-optimism-poll

African development bank (2018). Nigeria economic outlook. Retrieved from https://www.afdb.org/en/countries/west-africa/nigeria/nigeria-economic-outlook/

Ahmadov A. (2012). Political Determination of Economic Diversification in a Natural Resources Rich Developing Countries. Retrieved from https://www.princeton.edu/ pcglobal/conferences/GLF/ahmadov.pdf

Akoni, O., \& Olowoopejo, M. (2013, May 17). Lagos residents spend N1bn monthly on merriment. Vanguard. Retrieved from https:/www.vanguardngr.com/2013/05/lagos-residents-spend-n1bnmonthly-on-merriment-govt/

Alli, F. (2009). 820 manufacturing companies close down in 9 years- MAN. Vanguard. Retrieved from https://www.vanguardngr.com/2009/07/820-manufacturing-companies-close-down-in-9-yearsman/

ATA-Nigeria (n.d.). Federal Ministry of Agriculture and Rural Development. Retrieved from https://fmard.gov.ng/ata-nigeria/

Aziken, E. (2016, December 28). The year when a padded budget got missing. Vanguard. Retrieved from https://www.vanguardngr.com/2016/12/year-padded-budget-got-missing/ 
Bond, M. (2003, October 4). The pursuit of happiness. New Scientist. Retrieved from https://www.google.com/amp/s/www.newscientist.com/article/mg18024155-100-the-pursuit-ofhappiness/amp/

Carpenter, W. J. (2015, October 15). The biggest oil producers in Africa. Investopedia. Retrieved from https://www.investopedia.com/articles/investing/101515/biggest-oil-producers-africa.asp

Channels Television (2012, April 5). Denmark overtakes Nigeria as world's happiest people - UN. Retrieved from https://www.channelstv.com/2012/04/05/denmark-overtakes-nigeria-as-worldshappiest-people-un/

Channels Television (2015, March 7). Osun traditional rulers endorse President Jonathan. Retrieved from https://www.channelstv.com/2015/03/07/osun-traditional-rulers-endorse-president-jonathan/

Clement, U. (2017, June 11). "Fg breaks monopoly in free trade zones to create thousands of jobs". Vanguard. Retrieved from https://www.vanguardngr.com/2017/06/fg-breaks-monopoly-freetrade-zones-create-thousands-jobs/

Coleman, J. (1958). Nigeria: Background to nationalism. Berkeley, California: University of California Press

Countries: Nigeria (n.d.) World Health Organization. Retrieved from http://www.who.int/countries/nga/en/

Country Comparison: Crude oil - exports (n.d.). Central Intelligence Agency: The world factbook. Retrieved from https://www.cia.gov/library/publications/resources/the-worldfactbook/rankorder/2242rank.html

Country Comparison: Crude oil - production (n.d.). Central Intelligence Agency: The world factbook. Retrieved from https://www.cia.gov/library/publications/resources/the-worldfactbook/rankorder/2241rank.html

Country Comparison: Crude oil - proved reserves (n.d.). Central Intelligence Agency: The world factbook. Retrieved from https://www.cia.gov/library/publications/resources/the-worldfactbook/rankorder/2244rank.html

Daniel. (2014, February 16). Jonathan in surprise visit to palaces of four foremost traditional rulers. Information Nigeria. Retrieved from http://www.informationng.com/2014/02/photonewsjonathan-in-surprise-visit-to-palaces-of-four-foremost-traditional-rulers.html

Dibie, M. I. (2017, November 1). Nigeria reclaims position as Africa's top oil producer. Africa News. Retrieved from http://www.africanews.com/2017/01/11/nigeria-reclaims-position-as-africas-topoil-producer//

Economic report fourth quarter 2017. (n.d.). Central Bank of Nigeria. Retrieved from https://www.cbn.gov.ng/Out/2018/RSD/CBN\%20ECONOMIC\%20REPORT\%20FOURTH\%20 QUARTER\%20\%20\%20\%202017\%20Published.pdf

Enahoro, P. (1966). How to be a Nigerian. London: Spectrum Books Limited

Field listing: Crude oil - proved reserves. (n.d.). Central Intelligence Agency: The world factbook. Retrieved from https://www.cia.gov/library/publications/resources/the-worldfactbook/fields/2244.html\#36

Findlay, J. (2017, April 25). Largest ethnic groups in Nigeria. World atlas. Retrieved from https://www.worldatlas.com/articles/largest-ethnic-groups-in-nigeria.html

Five things you should know about Paris Club. (2017, July 20) Punch. Retrieved from http://punchng.com/five-things-you-should-know-about-paris-club/

Freedom House. (2017). "Freedom in the World 2017: Nigeria". Retrieved from https://freedomhouse.org/report/freedom-world/2017/nigeria.

Frenkiel, O. (2005, July 12) "One woman's war with fake drugs". British Broadcasting Corporation.

Retrieved from http://news.bbc.co.uk/2/hi/programmes/this_world/4656627.stm

Geertz, C. (1973). The interpretation of cultures: selected essays. Journal of Comparative Physiology B. New York: Basic Books, Inc. 
Gioia, D. A., Patvardhan, S. D., Hamilton, A. L., \& Corley, K. G. (2013). Organizational Identity formation and change. The Academy of Management Annals, 7(1), 123-193. https://doi.org/10.1080/19416520.2013.762225

Glynn, M. A. \& Watkiss, L. (2012). Exploring cultural mechanisms of organizational identity construction. In M. Schultz, S. Maguire, A. Langley, H. Tsoukas (Eds.), Constructing identity in and around organizations (pp. 63-88). New York: Oxford University Press.

Gov.UK. (n.d.). "Exporting to Nigeria" Retrieved from https:/www.gov.uk/government/uploads/system/uploads/attachment_data/file/572979/NIGERIA Guide2116.pdf

Gov.uk. (n.d. B). "Foreign travel advice Nigeria: Local laws and customs". Retrieved from https://www.gov.uk/foreign-travel-advice/nigeria/local-laws-and-customs

Grunig, L. A., Grunig, J. E., \& Verčič, D. (1998). Are the IABC's excellence principles generic? Comparing Slovenia and the United States, the United Kingdom and Canada. Journal of Communication Management, 2, 335-356. https://doi.org/10.1108/eb023475

Hall, E. T. \& Hall, M. R. (1990). Understanding cultural differences: Germans, French and Americans. Boston, MA: Intercultural Press.

Haouas, I., \& Heshmati, A. (2014). Can the UAE avoid the oil curse by economic diversification? St. Louis: Federal Reserve Bank of St Louis. Retrieved from https://search-proquestcom.ezproxy.lib.purdue.edu/docview/1698648874?accountid=13360

Hatch, M. J., \& Schultz, M. (1997). Relations between organizational culture, identity and image. European Journal of Marketing, 31(5/6), 356-365. https://doi.org/10.1108/eb060636

Hatch, M. J., Schultz, M., \& Skov, A.-M. (2015). Organizational identity and culture in the context of managed change: Transformation in the Carlsberg Group, 2009-2013. Academy of Management Discoveries, 1(1), 58-90. https://doi.org/10.5465/amd.2013.0020

Hodess, R. (2004). "Transparency international, Where did the money go?” In Transparency International Global Corruption Report 2004. Pluto press, London. Retrieved from https://www.transparency.org/whatwedo/publication/global_corruption_report_2004_political_co rruption

Hofstede, G. (1991) Cultures and organizations: Software of the mind. London: Harper Collins Business. Hofstede, G. (1994) Cultures and organizations: Software of the mind. London: Harper Collins Business.

Hofstede insights. (n.d.). Country comparison: Nigeria. Retrieved from https://www.hofstedeinsights.com/country-comparison/nigeria/

Igwebuike, E, Abioye, T \& Chimuanya, L. (2016). A pragma-semiotic analysis of 'Occupy Nigeria Group' online posts on the 2012 fuel subsidy removal in Nigeria. Journal of Visual Literacy, 35(3). pp. 201-214

International Monetary Fund. (2005, December 19). Nigeria: Poverty Reduction Strategy PaperNational Economic Empowerment and Development Strategy. IMF staff country reports. Retrieved from https://www.imf.org/en/Publications/CR/Issues/2016/12/31/Nigeria-PovertyReduction-Strategy-Paper-National-Economic-Empowerment-and-Development-18767

InterNations. (n.d.). Business etiquette in Nigeria. Retrieved from https://www.internations.org/nigeriaexpats/guide/working-in-nigeria-15535/business-etiquette-in-nigeria-3

Jack, G., \& Lorbiecki, A. (2007). National identity, globalization and the discursive construction of organizational identity. British Journal of Management, 18(1). pp.79-95. http://dx.doi.org/10.1111/j.1467-8551.2007.00527.x

Jadesimi, A. (2015, September 8). "Have monopolies in Nigeria smothered this trillion dollar market for 50 years?". Forbes. Retrieved from https://www.forbes.com/sites/amyjadesimi/2015/09/08/havemonopolies-in-nigeria-smothered-this-trillion-dollar-market-for-50-years/\#51 f58f362ef4

Johnson, K. (2010). Sexual harassment in the workplace: a case study of Nigeria. African Journal Online, 8(1). http://dx.doi.org/10.4314/gab.v8i1.54708 
Johnson, L. (n.d.). "Professor Dora Akunyili: Preventing Medical "Mass Murder" in Nigeria". Safe world for women. Retrieved from https://www.asafeworldforwomen.org/globalnews/africa/nigeria/4754-professor-akunyili.html

Jones, C. (n.d.) Top 6 photos of the Nigerian senate fighting. Naij.com [Blog]. Retrieved from https://www.naija.ng/904301-top-5-photos-that-prove-the-nigerian-senate-has-nochill.html\#904301

Kaplan, D., \& Manners, R.A. (1972). Culture theory. Englewood Cliffs, NJ: Prentice-Hall.

Karuga, J. (2017, April 25). 15 Biggest Cities In Africa. World Atlas. Retrieved from https://www.worldatlas.com/articles/15-biggest-cities-in-africa.html

Khari, C., \& Sinha, S. (2017). Impact of workplace spirituality on knowledge sharing intention: A conceptual framework. Journal of Human Values, 23(1), 27-39. https://doi.org/10.1177/0971685816673484

Kjærgaard, A., Morsing, M., \& Ravasi, D. (2011). Mediating identity: A study of media influence on organizational identity construction in a celebrity firm. Journal of Management Studies, 48(3). pp. 514-543. http://dx.doi.org/10.1111/j.1467-6486.2010.00954.x

Koper, E., Babaleye, T., Jahansoozi, J. (2009). Public relations practice in Nigeria In K. Sriramesh \& D, Verčič (Eds.), The global public relations handbook: Theory, research and practice (pp. 312 330). New York, NY: Routledge

Ladebo, O. J. (2003). Sexual harassment in academia in Nigeria: How Real? African Sociological Review / Revue Africaine de Sociologie, 7(1). pp. 117-130

Lagos parallel market rates. (n.d.) abokiFX. Retrieved from https://abokifx.com

LASG: Yoruba Now Mandatory for Admission into Tertiary Institutions in Lagos. (2018, February 12). This Day. Retrieved from https://www.thisdaylive.com/index.php/2018/02/12/lasg-yoruba-nowmandatory-for-admission-into-tertiary-institutions-in-lagos/

Lustig, M., \& Koester, J. (2013). Intercultural competence: Interpersonal communication across cultures. Upper Saddle River, N.J.: Pearson Prentice Hall

Mbachu, O. (1991). Strains and economic demand of structural adjustment programme in Nigeria: some implications. Africa: Rivista trimestrale di studi e documentazione dell'Istituto italiano per l'Africa e l'Oriente, 46(3). pp. 427 - 439

Mogo, E. R. I. (2016). A mixed-methods study on urban health and community resilience in the Lagos metropolis (Doctoral dissertation). Retrieved from https://search-proquestcom.ezproxy.lib.purdue.edu/docview/1868501600/?pq-origsite=primo

National bureau of statistics. (n.d.). Retrieved from http://nigerianstat.gov.ng

National bureau of statistics. (2017, December). Labor force statistics vol. 1: Unemployment and underemployment report. Retrieved from http://nigerianstat.gov.ng/elibrary?queries[search]=unemployment

Nigeria. (n.d.). Ethnologue: Languages of the World. Retrieved from https://www.ethnologue.com/country/NG

Nigeria country profile. (2017, October 10). British Broadcasting Corporation. Retrieved from http://www.bbc.com/news/world-africa-13949550

Nigeria economic outlook. (2018, February 20). Focus economics. Retrieved from https://www.focuseconomics.com/countries/nigeria

Nigeria economy: Economy overview. (n.d.). Embassy of Nigeria, Algiers - Algeria. Retrieved from http://www.nigeriaembassy-dz.org/nigeria/economy1.php

Nigeria: Life expectancy. (n.d.). World health rankings. Retrieved from http://www.worldlifeexpectancy.com/nigeria-life-expectancy

Nigeria: Past, present and future. (n.d.). Embassy of the Federal Republic of Nigeria, Washington D.C. Retrieved from http://www.nigeriaembassyusa.org/index.php?page=nigeria-past-present-andfuture

Nigeria profile - Timeline. (2017, October 10). British Broadcasting Corporation. Retrieved from http://www.bbc.com/news/world-africa-13951696 
Nigeria's GDP: Step change. (2014, April 12). The Economist. Retrieved from https://www.economist.com/news/finance-and-economics/21600734-revised-figures-shownigeria-africas-largest-economy-step-change

Nigeria's population now 182 million-NPC. (2017, May 14). National Population Commission. Retrieved from http://population.gov.ng/nigerias-population-now-182-million-npc/

Nigeria tops happiness survey. (2003, October 2). British Broadcasting Corporation. Retrieved from http://news.bbc.co.uk/2/hi/africa/3157570.stm

O’Neill, J., Wilson, D., Purushothaman, R., \& Stupnytska, A. (2005, Dec. 1). How solid are the BRICs? Goldman Sachs: Global Economics Paper, 134. Retrieved from https://www.goldmansachs.com/insights/archive/archive-pdfs/how-solid.pdf

Oriola, T. (2005). Advance fee fraud on the internet: Nigeria's regulatory response. Computer Law \& Security Review, 21(3), 237-248. https://doi.org/10.1016/j.clsr.2005.02.006

Osemeke, N. \& Osemeke. L. (2017). The effect of culture on corporate governance practices in Nigeria. International Journal of Disclosure and Governance, 14 (4), 318-340. http://dx.doi.org/10.1057/s41310-017-0028-5

Palk, S. (2010). When yes means maybe: Doing business in Nigeria. CNN. Retrieved from http://edition.cnn.com/2010/BUSINESS/08/31/business.etiquette.nigeria/index.html

Pant, A. \& Ojha, A. K. (2017). Managerial values and organizational identities in the developing world: An introduction to the special Issue. Journal of Human Values, 23(1), vii-xii.

Papa, M. J., Daniels, T. D. \& Spiker, B. K. (2008). Organizational communication: Perspectives and trends. Thousand Oaks, CA: Sage Publications

Parsons, T. \& Shils, E. A. (1951). Toward a general theory of action. Cambridge, MA: Harvard University Press.

Premium Times. (2012, September 11). 800 companies shut down in 3 years, says NACCIMA. Retrieved from https:/www.premiumtimesng.com/business/99757-800-companies-shut-down-in-3-yearssays-naccima.html

Prinz, J. J. (2012). Beyond humannNature: How culture and experience shape the human mind. New York: W. W. Norton \& Company. https://doi.org/10.1017/CBO9781107415324.004

Redding, C., \& Tompkins, P. (1988). Organizational communication-Past and future tenses. In G. Goldhaber \& G. Barnett (Eds.), Handbook of organizational communication (pp. 5-34). Norwood, NJ: Ablex.

Rosenthal, E. (2012, April 14). Nigeria tested by rapid rise in population. New York Times. Retrieved from http://www.nytimes.com/2012/04/15/world/africa/in-nigeria-a-preview-of-an-overcrowdedplanet.html

Sahu, V. (2017). Corruption: "Culture" in the dock. Journal of Human Values, 23(1), 21-26. https://doi.org/10.1177/0971685816673481

Saibu, O. M., \& Loto, M. A. (2017). Macroeconomic implications of economic diversification and oil resource curse on sustainable development in Nigeria. Journal of Sustainable Development in Africa, 19(3), 206-217

Scott, S. G. \& Lane, V. R. (2000). A stakeholder approach to organizational identity. Academy of Management Review, 25(1), 43-62.

Sdunkwu (2017, July 12). Only 600,000 Lagos residents pay tax out of $22 \mathrm{~m}$ population- Ambode. Lagos State Government: News. Retrieved from https://lagosstate.gov.ng/blog/2017/07/12/only-600000lagos-residents-pay-tax-out-of-22m-population-ambode/

Shapiro, D. (2014). Doing business in Nigeria. Journal of Corporate Accounting \& Finance, 25(6). pp. 36. https://doi.org/10.1002/jcaf.21981

Smith, R. G., Holmes, M. N., \& Kaufmann, P. (1999). Nigerian advance fee fraud. Trends and issues in crime and criminal justice. 121. Retrieved from https://beta2.finance.si/upload/pavel/pavel3cf4fa4c8cdf1/nigeria\%20advanced\%20fraud.pdf 
Spencer-Oatey, H. (2012). "What is culture?” GlobalPAD Core Concepts. Retrieved from https://www2.warwick.ac.uk/fac/soc/al/globalpad/openhouse/interculturalskills/global_pad_what_is_culture.pdf

Sriramesh, K., \& Verčič, D. (2009). The global public relations handbook: Theory, research, and practice ( $2^{\text {nd }}$ edition). New York: Routledge.

Transparency International. (2017, January 25). "Corruption Perceptions Index 2016". Retrieved from https://www.transparency.org/news/feature/corruption_perceptions_index_2016

Transparency International. (2018, February 21). "Corruption Perceptions Index 2017”. Retrieved from https://www.transparency.org/news/feature/corruption_perceptions_index 2017

Wallace, R.S.O. 1992. The growing pains of an indigenous accounting profession. Accounting, Business and Financial History, 2. pp. 25-53

Wesseling, H. L. (1996). Divide and rule: The partition of Africa, 1880-1914. West Port, CT: Praeger.

White, J. (1987A) 'Professional Development Needs of UK Public Relations Practitioners', Institute of Public Relations, London.

White, J., Hammonds, L. \& Kalupa, F. (1987B) "Professional Development Needs of U.S. Public Relations Practitioners", paper presented at the meeting of the Association for Education in Journalism and Mass Communication, San Antonio, TX, August.

White, J., \& Trask, G. (1982) Professional development needs of Canadian Public Relations practitioners. Halifax, Nova Scotia: Dalhousie University, Canadian Public Relations Society and Advanced Management Centre. 